Terakreditasi Sinta 3 | Volume 3 | Nomor 4 (Special Issue) | Tahun 2020 | Halaman 385-392

P-ISSN 2615-725X | E-ISSN 2615-8655

http://diglosiaunmul.com/index.php/diglosia/article/view/87

\title{
KALIMAT IMPERATIF DALAM IKLAN LAYANAN MASYARAKAT BERBAHASA ARAB TERKAIT COVID-19 DI SBS AUSTRALIA
}

\author{
Imperative Sentences in Arabic Language in Community Service Advertising \\ Related to Covid-19 in SBS Australia
}

\author{
Trian Ramadhan Nuryadin ${ }^{1, *}$ dan Wagiati ${ }^{2}$ \\ ${ }^{1,2}$ Fakultas Ilmu Budaya, Universitas Padjadjaran \\ ${ }^{1, *}$ Pos-el korespondensi: trianrn33@gmail.com \\ ${ }^{2}$ Pos-el: wagiati@unpad.ac.id
}

\begin{abstract}
Social networking media became the main media to spread public service announcements related to Covid19 during a pandemic to prevent the spread of this outbreak. This study focuses on imperative sentences on public service Arabic announcements related to Covid-19 issued by SBS Australia. The purpose of this study is to describe the structure of imperative sentence forms in these advertisements syntactically and to group them into imperative sentence types according to Alwi (2010). This research is included in the research type of descriptive analysis research. The data analysis method used in this study is a method of distribution with the basic technique for direct elements (BUL) which is used to describe and analyze data from data sources. This study found as many as; 5 data are categorized as imperative commands or ordinary orders, 1 data are categorized as imperative subtle commands, 2 data are categorized as imperatives and invitations, 2 data are categorized as imperative probibitions or negative commands. In addition, the imperative sentence in this ad is preceded by the structure of the predicate-object-complement-description sentence.

Keywords: imperative sentences, Covid-19, public service advertisement, syntax
\end{abstract}

\begin{abstract}
Abstrak: Media jejaring sosial menjadi media utama untuk menyebarkan iklan layanan masyarakat terkait Covid-19 pada saat pandemik untuk mencegah penyebaran wabah ini. Penelitian ini berfokus pada kalimat imperatif pada iklan layanan masyarakat terkait Covid-19 berbahasa Arab yang di keluarkan oleh SBS Australia. Tujuan dari penelitian ini adalah untuk mendeskripsikan struktur bentuk kalimat imperatif dalam iklan tersebut secara sintaksis serta mengelompokkannya dalam jenis kalimat imperatif menurut Alwi (2010). Penelitian ini termasuk dalam penelitian jenis penelitian analisis deskriptif. Metode analisis data yang digunakan dalam penelitian ini adalah metode agih dengan teknik dasar bagi unsur langsung (BUL) yang digunakan untuk mendeskripsikan dan menganalisis data dari sumber data. Pada penelitian ini ditemukan sebanyak; 5 data tergolong dalam kata imperatif perintah atau suruhan biasa, 1 data tergolong dalam kata imperatif perintah halus, 2 data tergolong dalam kata imperatif ajakan dan harapan, 2 data tergolong dalam kata imperatif larangan atau perintah negatif. Selain itu kalimat imperatif dalam iklan ini diawali oleh struktur kalimat predikat-objek-pelengkap-keterangan.
\end{abstract}

Kata kunci: kalimat imperatif, Covid-19, iklan layanan masyarakat, sintaksis

\section{A. PENDAHULUAN}

Satuan lingual berupa kalimat dapat dijadikan objek kajian penelitian. kalimat dapat bersumber dari tuturan yang bersifat lisan maupun tulisan. Suatu contoh kalimat yang dituturkan secara lisan dapat diamati dari berbagai media elektronik, seperti jejaring sosial dan media daring. Melalui media daring kita dapat menemukan berbagai jenis kalimat dengan struktur dan isi yang sangat beragam, salah satunya ialah kalimat imperatif. 
Menurut Alwi et al. (2010) sebuah kalimat paling tidak mengandung unsur subjek dan predikat serta telah dibubuhi intonasi atau tanda baca Tanpa adanya intonasi akhir atau tanda baca, deretan kata tidak bisa disebut sebagai suatu kalimat, melainkan hanya sebagai satuan lingual yang berupa klausa. Kalimat dengan penandanya berupa intonasi akhir di antaranya dapat dilihat pada iklan layanan masyarakat di media sosial dan media daring.

Pada akhir tahun 2019 dunia di hebohkan dengan lahirnya virus baru yang disebut Covid-19, virus tersebut berkembang dan bertransmisi melalui hubungan sosial manusia, WHO (World Healt Organization) mengumumkan bahwa Covid-19 merupakan pandemik internasional yang perlu diwaspadai oleh seluruh lapisan masyarakat di dunia, mengingat penyebarannya begitu cepat. Pemerintah di setiap negara bergerak cepat untuk menanggulangi setiap poin yang akan membuat penyebaran semakin memburuk. Australia merupakan negara yang memiliki banyak ras dan suku dari berbagai macam negara, salah satunya adalah negara Timur Tengah yang menggunakan bahasa Arab sebagai bahasa ibunya.

Media sosial Youtube tidak asing lagi bagi masyarakat milenial pada zaman yang berkembang seperti ini. Di masa pandemik seperti ini media daring merupakan media yang sangat efektif sebagai media yang dapat menyebarkan informasi secara cepat. Pemerintah Australia memulai membuat iklan layanan masyarakat terkait Covid-19 yang disebarkan di setiap media daring. SBS Australia merupakan media swasta lokal yang bergerak dalam TV dan radio, namun SBS Australia mengunggah beberapa iklan masyarakat di media daring Youtube.

Pada iklan layanan masyarakat terkait Covid-19 pemerintah menghimbau pergerakan masyarakat Australia untuk mencegah penularan virus ini secara sepat.
Pentingnya pembatasan sosial dan pembatas fisik pada wabah ini perlu di sadari oleh setiap lapisan warga di Australia. Salah satunya adalah komunitas lokal yang berasal dan berbahasa Arab.

Tuturan yang berisi permintaan merupakan contoh realisasi dari kalimat, khususnya kalimat dengan penandanya yang berupa intonasi. Jika dilihat dari bentuk sintaksisnya, kalimat permintaan termasuk dalam jenis kalimat imperatif (perintah). Kalimat imperatif adalah mode imperatif yang berfungsi untuk membantu penyampaian pesan terhadap pendengar untuk berbuat atau melarang sesuatu (Hao \& Shi, 2018). Perintah atau suruhan dan permintaan jika ditinjau dari isinya, dapat diperinci menjadi enam jenis, yakni: (1) perintah atau suruhan biasa, (2) perintah halus, (3) permohonan, (4) ajakan dan harapan, (5) larangan atau perintah negatif, serta (6) pembiaran (Alwi et al., 2010, hlm. 353).

Sejalan dengan itu, Alisjahbana (juga membedakan kalimat imperatif menjadi empat macam, yaitu: (1) perintah yang menunjuk pada suatu kewajiban, (2) perintah yang bermakna mengejek, (3) perintah yang bermaksud memanggil, dan (4) perintah yang merupakan permintaan (Rahardi, 2005). Berdasarkan klasifikasi kalimat imperatif tersebut, kalimat yang digunakan sebagai objek dalam penelitian ini termasuk dalam golongan kalimat perintah yang isinya berupa permohonan atau permintaan. Alwi et al. (2010) menjelaskan bahwa kalimat imperatif permintaan biasanya menggunakan satuan lingual penanda berupa kata mohon dan minta.

Menurut Supratman dalam Putrayasa (2012) bahwa kalimat perintah digunakan sebagai sumber untuk kalimat imperatif yang ditambah dengan intonasi perintah. Secara umum, kalimat imperatif mempunyai kemungkinan struktur (1) struktur S-P, (2) struktur P-S, (3) struktur Ket. Modal-S-P, (4) struktur P-O, (5) Struktur P, (6) struktur oleb+kamu, (7) 
struktur jangan/tidak, dan (8) struktur biar.

Penelitian tentang kalimat imperatif memang sudah cukup banyak jumlahnya, baik kalimat imperatif dalam bahasa Indonesia maupun bahasa daerah. Namun dalam penelitian ini peneliti meneliti kalimat imperatif dalam bahasa Arab dalam iklan layanan masyarakat untuk komunitas lokal arab di Australia. Penelitian ini memiliki perbedaan dari penelitian-penelitian sebelumnya, di mana peneliti di sini meneliti bahasa Arab yang mana bahasa ini merupakan bahasa fleksi. Peneliti dituntut untuk membedakan naik turunnya vokal dan intonasi sebagai penanda kalimat imperatif. Sebagaimana dijelaskan oleh Nuryani (2014) dalam hasil penelitiannya dijelaskan bahwa kalimat imperatif dalam bahasa Jawa ditandai oleh beberapa hal, seperti penggunaan tanda baca dengan intonasi tertentu, yang predikatnya mendapatkan akhiran $-e n,-a$, -ana, atau -na, dan dapat ditambah dengan kata penunjuk perintah seperti: ayo, sumangga, mangga, dan coba.

Telah dibahas sebelumnya bahwa kalimat setidaknya mengandung subjek dan predikat dengan penanda berupa tanda baca atau intonasi tertentu. Penelitian ini bertujuan untuk menjelaskan pola, struktur, dan penanda dalam kalimatkalimat imperatif permintaan lisan yang terdapat pada iklan layanan masyarakat terkait Covid-19 untuk masyarakat lokal arab di Australia. Teori-teori yang berkaitan dengan struktur kalimat akan dijadikan dasar sekaligus pembanding dalam upaya menjelaskan fenomenafenomena kebahasaan pada kalimat imperatif permintaan yang ditemukan pada iklan tersebut.

\section{B. METODE}

Penelitian ini termasuk dalam penelitian jenis penelitian deskriptif kualitatif. Data yang digunakan dalam penelitian ini berupa kalimat imperatif permintaan yang bersumber dari tayangan iklan layanan masyarakat terkait Covid-19 berbahasa Arab yang dikeluarkan oleh SBS Australia yang diambil dari situs Youtube. Pengambilan data penelitian ini dilakukan dengan menggunakan teknik simak dan catat. Teknik ini dilakukan dengan cara mengadakan simak terhadap pemakaian bahasa lisan dan mengadakan pencatatan terhadap data relevan yang sesuai dengan sasaran dan tujuan penelitian (Subroto, 2011). Selanjutnya data ditranskripsi ke bahasa Arab dan diterjemahkan ke bahasa Indonesia, agar memudahkan penulis dalam menganalisis data dan memudahkan pembaca artikel ke depanya.

Realisasi dari teknik pengambilan data tersebut adalah dengan cara mengunduh tayangan iklan layanan masyarakat terkait Covid-19 berbahasa Arab yang dikeluarkan oleh SBS Australia dari Youtube untuk dipahami dan kemudian ditranskripsi percakapannya guna mendapatkan data penelitian yang berupa kalimat imperatif permintaan.

Data berupa kalimat inilah yang kemudian dianalisis dan disajikan hasilnya. Metode analisis data yang digunakan dalam penelitian ini adalah metode agih dengan teknik dasar bagi unsur langsung (BUL). Sudaryanto (2015) menjelaskan bahwa prinsip kerja metode agih itu jelas selalu berupa bagian atau unsur dan bahasa objek sasaran penelitian itu sendiri, seperti kata (kata ingkar, preposisi, adverbia, dsb), fungsi sintaktis (subjek, objek, predikat, dsb), klausa, silabi kata, titi nada, dan yang lain. Teknik lanjutan yang digunakan untuk analisis data adalah teknik sisip dan ganti. Teknik dasar BUL dilakukan dengan cara membagi unsur-unsur pembangun dalam kalimat seperti subjek, predikat, objek, keterangan maupun pelengkap, sesuai yang ditemukan dalam data.

Ungkapan Minta perhatian, Saudarasaudara! merupakan contoh kalimat imperatif permintaan. Jika dianalisis menggunakan teknik dasar BUL, kalimat tersebut dapat dibagi menjadi beberapa unsur pembangun kalimat, yakni kata 
minta yang berperan sebagai predikat, kata perhatian sebagai objek dan saudara-saudara yang berperan sebagai pelengkap kalimat yang berupa kata sapaan. Dengan menggunakan teknik BUL dapat diketahui bahwa contoh kalimat imperatif permintaan tersebut tidak mempunyai unsur yang berperan sebagai subjek.

Setelah melalui proses analisis dengan menggunakan teknik dasar, data akan dianalisis menggunakan teknik lanjutan, yaitu teknik sisip dan ganti. Teknik sisip adalah teknik yang dilaksanakan dengan menyisipkan unsur tertentu di antara unsur-unsur lingual yang ada, sedangkan teknik ganti adalah teknik yang dilaksanakan dengan menggantikan unsur tertentu satuan lingual yang bersangkutan dengan unsur tertentu lain di luar satuan lingual yang bersangkutan (Sudaryanto, 2015). Teknik sisip dalam penelitian ini digunakan untuk mengetahui keberterimaan kalimat imperatif permintaan yang satu atau lebih unsur pembangun kalimatnya tidak diketahui, seperti contoh kalimat di atas. Telah dijelaskan sebelumnya bahwa kalimat "Minta perhatian, Saudara-saudara!" adalah kalimat yang tidak memiliki subjek. Meskipun demikian, secara teoretis, subjek sebagai pelaku dalam jenis kalimat imperatif semacam ini memang biasanya tidak muncul dalam kalimat.

Penerapan teknik lanjutan sisip dalam contoh kalimat tersebut dapat dilakukan dengan cara menyisipkan satu kata ganti orang pada posisi subjek, misalnya: kata saya, sehingga kalimat tersebut menjadi "(Saya) minta perbatian, Saudara-saudara!". Setelah disisipi kata saya, contoh kalimat tersebut secara semantik dan gramatikal akan lebih berterima. Jenis kalimatnya juga tidak mengalami perubahan, yaitu kalimat imperatif permintaan. Penerapan yang hampir sama juga berlaku dalam penggunaan teknik lanjutan ganti, yang dilakukan dengan cara mengganti unsurunsur yang disisipkan dalam kalimat. Sebagai contoh, kalimat "(Saya) minta perbatian, Saudara-saudara!" merupakan kalimat yang telah disisipi kata saya sebagai subjek. Jika kata saya diganti dengan kata ganti orang ketiga berupa kata dia, maka kalimatnya akan menjadi "(Dia) minta perbatian, Saudara-saudara!"

Kalimat tersebut secara semantik dan gramatikal memang masih berterima, akan tetapi jika diamati lebih saksama jenis kalimatnya bukan lagi kalimat imperatif permintaan, melainkan jenis kalimat deklaratif atau berita. Secara fungsional, kalimat deklaratif memiliki sifat yang berbeda dengan kalimat imperatif permintaan. Umumnya, kalimat deklaratif digunakan oleh pembicara untuk membuat pernyataan yang isinya merupakan berita bagi pendengar atau pembacanya (Alwi et al., 2010). Dapat dikatakan bahwa teknik lanjutan ganti ini digunakan untuk melengkapi teknik lanjutan sisip untuk mengetahui kemungkinan perubahan jenis kalimat yang terjadi jika disisipkan suatu kata pada salah satu posisi unsur pembangun kalimat.

Setelah itu hasil transkrip akan dikategorikan sesuai dengan teori Alwi et al. (2010) tentang kalimat imperatif. Seperti yang telah disinggung sebelumnya perintah atau suruhan dan permintaan jika ditinjau dari isinya, dapat diperinci menjadi enam jenis, yakni: (1) perintah atau suruhan biasa, (2) perintah halus, (3) permohonan, (4) ajakan dan harapan, (5) larangan atau perintah negatif, serta (6) pembiaran (Alwi et al., 2010, hlm. 361).

\section{PEMBAHASAN}

Setelah mentranskripsi data yang didapat dari sumber data, penulis menerjemahkan iklan tersebut ke dalam bahasa Indonesia. Setelah diterjemahkan peneliti menyaring data dan menemukan 8 paragraf yang mengandung kalimat imperatif. 


\section{لمنع انتشار فيروس كورونا، من الضروري أن

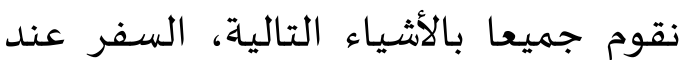 \\ الضرورة فقط.}

(Untuk mencegah penyebaran virus Corona, sangatlah penting agar kita semua melakukan hal-hal berikut, hanya lakukan perjalanan yang esensial.)

$$
\text { إبق مسافة } 1.5 \text { متر عل الأل بينك وبين أي النظافة الجيدة ضرورئة. لا تصافح ولا تعانق أحدا. }
$$

Jagalah jarak setidaknya 1,5 meter dari orang lain, jangan berjabat tangan atau berpelukan. Sangatlah penting untuk. menjaga kebersiban.)

$$
\text { غطي فمك عند السعال بكوعك أو باستخدام }
$$

Mobon tutupi mulut Anda saat batuk dengan siku atau tisu, lalu buang ke tempat sampah.)

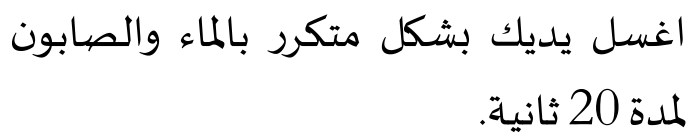

(Sering-seringlah mencuci tangan dengan sabun dan air selama 20 detik.)

$$
\text { نظف وطهر الأسطح بانتظام. }
$$

(Bersibkan dan disinfeksi permukaan-permukaan secara teratur.)

$$
\text { بأي شخا كنت مريضيا، تجنب الاتصبال الجسدي حتى في المنزل. واطلب المشورة }
$$

Jika Anda sakit, bindari semua kontak fisik dengan orang lain, babkean saat di rumah. Dan cari nasehat medis jika perlu.)

$$
\text { كن إيجابيا وابق على اتصال مع العالة }
$$

(Tetaplah positif dan terbubung dengan keluarga serta teman-teman Anda melalui telepon dan media sosial.)

$$
\begin{aligned}
& \text { واكب اخر الأخبار على الراديو والتلفزيون } \\
& \text { والإنترنت. }
\end{aligned}
$$

(Ikuti terus berita terbaru di radio, TV, dan Internet.)

Paparan hasil penelitian ini disusun berdasarkan jenis kategori kalimat imperatif yang ditemukan. Setelah menyaring data dalam 8 paragraf yang telah di terjemahkan, peneliti menemukan 10 data kalimat imperatif. Hasil penelitian secara umum menunjukkan bahwa 5 data tergolong dalam kata imperatif perintah atau suruhan biasa, 1 data tergolong dalam kata imperatif perintah halus, 2 data tergolong dalam kata imperatif ajakan dan harapan, 2 data tergolong dalam kata imperatif larangan atau perintah negatif.

Berikut ini adalah pemaparan hasil analisis jenis kalimat imperatif yang ditemukan dalam iklan layanan masyarakat terkait Covid-19 berbahasa Arab yang dikeluarkan oleh SBS Australia. 
Tabel 1. Data Penjenisan Kalimat Imperatif

\begin{tabular}{|c|c|c|}
\hline No. & Kalimat Imperatif & Jenis Kalimat Imperatif \\
\hline 1 & $\begin{array}{l}\text { Sering-seringlah mencuci tangan dengan sabun dan } \\
\text { air selama } 20 \text { detik. }\end{array}$ & Perintah atau suruhan biasa \\
\hline 2 & $\begin{array}{l}\text { Bersihkan dan disinfeksi permukaan-permukaan } \\
\text { secara teratur. }\end{array}$ & Perintah atau suruhan biasa \\
\hline 3 & Hanya lakukan perjalanan yang esensial. & Perintah atau suruhan biasa \\
\hline 4 & Dan cari nasehat medis jika perlu. & Perintah atau suruhan biasa \\
\hline 5 & Jagalah jarak setidaknya 1,5 meter dari orang lain, & Perintah atau suruhan biasa \\
\hline 6 & $\begin{array}{l}\text { Mohon tutupi mulut Anda saat batuk dengan siku } \\
\text { atau tisu, lalu buang ke tempat sampah }\end{array}$ & Perintah halus \\
\hline 7 & $\begin{array}{l}\text { Tetaplah positif dan terhubung dengan keluarga } \\
\text { serta teman-teman Anda melalui telepon dan media } \\
\text { sosial. }\end{array}$ & Ajakan dan harapan \\
\hline 8 & Ikuti terus berita terbaru di radio, TV, dan Internet. & Ajakan dan harapan \\
\hline 9 & $\begin{array}{l}\text { Jika Anda sakit, hindari semua kontak fisik dengan } \\
\text { orang lain, bahkan saat di rumah. }\end{array}$ & Larangan dan perintah negatif \\
\hline 10 & Jangan berjabat tangan atau berpelukan. & Larangan dan perintah negatif \\
\hline
\end{tabular}

Tabel 2. Kalimat Imperatif Perintah atau Suruhan Biasa

\begin{tabular}{cll}
\hline No. & Kalimat Imperatif & Penanda Kalimat Imperatif \\
\hline 1 & $\begin{array}{l}\text { Sering-seringlah mencuci tangan dengan sabun dan } \\
\text { air selama 20 detik. }\end{array}$ & Sering-seringlah/ -lah \\
2 & $\begin{array}{l}\text { Bersihkan dan disinfeksi permukaan-permukaan } \\
\text { secara teratur. }\end{array}$ & Bersihkan \\
3 & Hanya lakukan perjalanan yang esensial. & Lakukan \\
4 & Dan cari nasehat medis jika perlu. & Cari \\
5 & Jagalah jarak setidaknya 1,5 meter dari orang lain, & Jagalah/-lah \\
\hline
\end{tabular}

Tabel 3. Kalimat Imperatif Perintah Halus

\begin{tabular}{cll}
\hline No. & Kalimat Imperatif & Penanda Kalimat Imperatif \\
\hline 1 & $\begin{array}{l}\text { Mohon tutupi mulut Anda saat batuk dengan siku } \\
\text { atau tisu, lalu buang ke tempat sampah }\end{array}$ & Mohon \\
\hline
\end{tabular}

Tabel 4. Kalimat Imperatif Ajakan dan Harapan

\begin{tabular}{cll}
\hline No. & Kalimat Imperatif & Penanda Kalimat Imperatif \\
\hline 1 & $\begin{array}{l}\text { Tetaplah positif dan terhubung dengan keluarga serta } \\
\text { teman-teman Anda melalui telepon dan media sosial. }\end{array}$ & Tetaplah \\
2 & Ikuti terus berita terbaru di radio, TV, dan Internet. & Ikuti/-i \\
\hline
\end{tabular}

Tabel 5. Kalimat Imperatif Larangan dan Perintah Negatif

\begin{tabular}{cll}
\hline No. & Kalimat Imperatif & Penanda Kalimat Imperatif \\
\hline 1 & $\begin{array}{l}\text { Jika Anda sakit, hindari semua kontak fisik dengan orang } \\
\text { lain, bahkan saat di rumah. }\end{array}$ & Hindari \\
& Jangan berjabat tangan atau berpelukan. & Jangan \\
\hline
\end{tabular}




\section{Perintah atau Suruhan Biasa}

Kalimat imperatif dalam kategori perintah atau suruhan biasa, biasanya ditandai jika pembicara menyuruh lawan bicaranya berbuat sesuatu. Biasanya kategori ini tidak diberi tambahan kata untuk memulai suatu kalimat imperatif.

Pada data (1) dalam Tabel 2 ditemukan kata sering-seringlah yang menjadi penanda kalimat ini adalah kalimat imperatif. Partikel -lah menjadi penanda kalimat imperatif. Sering-seringlah merupakan keterangan waktu namun dalam kata ini menjadi verba karena adanya partikel -lah sehingga kata seringseringlah menjadi pengisi fungsi predikat. Kata mencuci merupakan verba semi transitif dan mengisi fungsi predikat 2 . Kata tangan menjadi objek, dan klausa dengan sabun dan air selama 20 detik merupakan pengisi fungsi keterangan waktu dan alat.

Pada data (2) dalam Tabel 2, kata bersibkan menjadi penanda kalimat imperatif. Kata bersib merupakan adjektiva namun karena ada penempelan partikel

-kan menjadi verba. Kata disinfeksi merupakan nomina, kata bersibkan dan disinfeksi merupakan predikat walaupun pada kata disinfeksi tidak memiliki partikel -kan untuk menjadikannya imperatif. Kata permukaan-permukaan mengisi fungsi objek, dan frasa secara teratur menjadi fungsi keterangan cara.

Pada data (3) dalam Tabel 2, kata lakukan menjadi penanda kalimat ini yang merupakan kalimat imperatif, banya lakukan perjalanan merupakan frasa, hanya lakukan menjadi predikat, dan kata perjalanan mengisi pelengkap, yang esensial merupakan perluasan pelengkap sebagai penjelas kata perjalanan.

Pada data (4) dalam Tabel 2, kata cari menjadi penanda bahwa kalimat ini adalah kalimat imperatif. Kata dan menjadi konjungsi, verba cari mengisi fungsi predikat. Frasa nasehat medis menjadi objek.
Pada data (5) dalam Tabel 2, verba jaga partikel -lab menjadi penanda bahwa kalimat tersebut kalimat imperatif. Verba jagalah menempati fungsi predikat, dan jarak menjadi objek. Klausa setidaknya 1,5 meter dari orang lain menempati fungsi keterangan cara. Tidak adanya kata tambahan seperti mobon, tolong, dan lainnya di awal kalimat menjadi penanda ini adalah kalimat imperatif perintah atau suruhan biasa.

\section{Perintah Halus}

Selain kalimat imperatif dalam kategori perintah biasa, bahasa Indonesia juga memiliki sejumlah kata yang dipakai untuk menghaluskan isi kalimat imperatif. Seperti kata tolong, coba, silakan, sudabilah, dan kiranya sering dipakai untuk maksud itu.

Pada data (1) dalam Tabel 3, kata mohon menjadi penanda untuk kata imperatif. Kata mohon menempati keterangan modal. Kata tutupi menempati fungsi predikat, frasa mulut Anda menjadi fungsi objek. Frasa saat batuk menjadi keterangan waktu, dengan siku atau tisu, lalu buang ke tempat sampah merupakan klausa yang memiliki fungsi keterangan cara.

\section{Ajakan dan Harapan}

Di dalam kalimat imperatif, ajakan dan harapan tergolong dalam kalimat yang biasanya didahului kata ayo(lah), mari(lah), harap, dan hendaknya.

Pada data (1) dalam Tabel 4, kata tetaplah menjadi verba ajakan berpartikel -lah yang menandai bahwa kalimat ini kalimat imperatif. Kata tetaplab menduduki fungsi predikat, frasa positif dan terbubung merupakan fungsi pelengkap. Klausa dengan keluarga serta teman-teman Anda melalui telepon dan media sosial mempunyai fungsi keterangan cara.

Pada data (2) dalam Tabel 4, sufiks -i menjadi penanda kalimat imperatif. Frasa ikuti terus menduduki fungsi predikat, frasa 
berita terbaru menjadi objek, dan frasa $d i$ radio, TV, dan Internet mempunyai fungsi keterangan tempat.

\section{Larangan dan Perintah Negatif}

Kalimat imperatif larangan dapat bersifat larangan dengan kata jangan(lab). Biasanya di akhir kata ditandai dengan tanda seru (!). Perhatikan pada data (1) dalam Tabel 5, kata hindari menjadi penanda bahwa kalimat imperatif. Verba bindari bersufiks $-i$ menduduki fungsi predikat, frasa semua kontak fisik menjadi fungsi objek, dengan orang lain, babkan saat di rumah merupakan klausa yang di dalamnya terdiri atas keterangan cara dan keterangan tempat.

Pada data (2) dalam Tabel 5, kata jangan menjadi penanda kalimat imperatif larangan. adverbia jangan menduduki fungsi predikat. Kata berjabat tangan dan berpelukan merupakan fungsi objek dan atau menjadi partikel.

\section{PENUTUP}

Setelah menganalisis jenis-jenis kalimat imperatif yang terdapat pada iklan layanan masyarakat terkait Covid-19 di SBS Australia, penulis dapat menyimpulkan bahwa dari iklan tersebut ditemukan sebanyak 10 data kalimat imperatif. Berdasarkan hasil analisis sesuai dengan teori Alwi et al. (2010) tentang jenis kalimat imperatif ditemukan sebanyak; 5 data tergolong dalam kata imperatif perintah atau suruhan biasa, 1 data tergolong dalam kata imperatif perintah halus, 2 data tergolong dalam kata imperatif ajakan dan harapan, 2 data tergolong dalam kata imperatif larangan atau perintah negatif. Selain itu kalimat imperatif dalam iklan ini diawali oleh struktur kalimat predikat-objekpelengkap-keterangan. Subjek pada kalimat imperatif pada sumber data tidak ditampilkan karena pelesapan subjek biasa ditemukan pada kalimat imperatif. Di samping itu, subjek dari semua kalimat imperatif pada iklan ini adalah pria pembawa berita SBS Australia keturunan Arab yang fasih berbahasa Arab.

\section{DAFTAR PUSTAKA}

Alwi, H. et al. (2010). Tata Bahasa Baku Bahasa Indonesia. Jakarta: Pusat Bahasa dan Balai Pustaka.

Zhao, H., \& Shi, S. (2014). The Formation of Modern Chinese Imperative Sentence Combining. International Conference on Asian Language Processing (IALP), 83-86.

Nuryani. (2014). "Kalimat Imperatif dalam Bahasa Jawa". Jurnal Dialektika, 1 (2)

Putrayasa, I. B. (2012). Jenis Kalimat Bahasa Indonesia. Bandung: Refika Aditama.

Rahardi, K. (2005). Pragmatik: Kesantunan Imperatif Bahasa Imperatif Babasa Indonesia. Jakarta: Erlangga.

Subroto, E. (2011). Pengantar Metode Penelitian Linguistik Struktural. Surakarta: UNS Press.

Sudaryanto. (2015). Metode dan Aneka Teknik Analisis Babasa. Yogyakarta: Sanata Dharma University Press. 